\title{
A Paixão de Sara: uma carta de amor regiana ou a errância em três tempos
}

\section{Resumo:}

Este artigo pretende demonstrar a cadência poética de Missa in Albis, bem como a perceção da palavra e, logo, da persona e seu discurso, como um exercício de escuta. "Quer ouvir?" repete-se como um motivo de instauração poética do mundo, pois "Tudo nos fala." Centrando o estudo essencialmente na figura de Sara, ler-se-á a sua Paixão como decalque-simulacro do poema regiano "Carta de Amor", na convocação temática do fingimento e do binómio arte/vida na poética de Maria Velho da Costa, pelo que se abordará o carácter ritualista de Sara, quer no que respeita à incursão pelo religioso, quer no que reflete a literatura (arte) enquanto voragem palimpséstica. Nesse sentido, e atendendo ao exercício lúdico de contrafação de sujeitos, veremos como Sara se virá a situar à beira Ebro ou no rio que assedia Münster.

Palavras-chave:

Escuta, fingimento, rito

\section{Abstract:}

This essay intends to discuss the poetic pace in Missa in Albis as well as the perception of word, speech and persona as a listening exercise. The analysis also reads Sara and her Passion towards a notion of simulacrum, a Passion drill of José Regio's "Carta de Amor". Therefore, Sara's ritualistic character, the religion and fiction dimension, and the palimpsestic conception of literature (art) are addressed by tracing Sara's personae dynamics to the banks of Münster.

\section{Keywords:}

Listening to, acting, rite

Nur Narr! Nur Dichter!

Friedrich Nietzsche

\section{Um - dos estados místicos}

Este trabalho pretende habilitar a noção de escuta como fenómeno fundamental da poética de Maria Velho da Costa, amplificada na construção de uma voz própria fundeada sobre o 
discurso interior, demonstrando que de Missa in Albis, obra aqui entendida como painel, ressoam ecos intertextuais alicerçados numa perspetivação eufónica e poética do mundo. Assim, Sara discursa-se como amplitude repercussiva e ritual da carta regiana e de outros evangelhos, reenunciação e atualização do mito, paralela à recitação litúrgica.

"Diga o que diga, - é só falar de Deus" afirma José Régio em "A coluna de fogo" (Régio 2001: 159). ${ }^{1}$ Convoca-se para esse diálogo de surdo-mudo/ poeta no lugar de Cristo da Paixão, identificando-se com a humanidade crucificada do filho do Criador. Em Missa in Albis, é Sara quem se convoca como filha da ritualista fazedora de figuras, cujo instrumento não é barro, mas papel e tesoura, desbastando.

Se a poesia de Régio é narrativizante, a narrativa de Maria Velho da Costa, poetizante. Lê-se tensionalidade em ambos. Escutar é recuperar a palavra. E há nisso grande ritual. Movimento para os outros, desmaio para o tinir inaugural do mundo, a prosa poetizante da autora desfolha o instituído, mergulha no sentido pela forma. ${ }^{2}$ No ritual de desescrita, artifício dramático, é conversando com o profano que a autora amplia o sagrado da escrita enquanto rito de partilha e comunhão, oração em continuum, Palavra que toma para a sua boca em manifesto blasfemo, reelaborando a linguagem, opondo-a à normatividade. "Quer ouvir?" convida, como ritual de citação permanente. A poesia da autora permite a receção/intuição por via sinestésica, indissociável do processo de estranhamento da linguagem. Agustina Bessa-Luís viria a falar de um fio de epilepsia, referindo-se ao vício de flanar, podendo ler-se o sintoma epilético como princípio de liberdade; no caso, este fio auditivo que é forçoso seguir no desbravar da palavra, da eufonia, verbalização primária dos sentidos. Jorge Luis Borges, na Inscriptión de Los Conjurados, diria que a cadência da palavra pode pesar mais do que o sentido, Maria Gabriela Llansol, que o sentido, afinal, "é impostura de língua"(Llansol 2016: 129), ${ }^{3}$ e Guimarães Rosa despede-se dizendo que a "gente morre para provar que viveu".4 Estes manifestos retinem na poética de Velho da Costa como configurações possíveis de uma pirâmide oblíqua em constante deflexão. De facto, Sara desfilia-se, na mesma proporção em que Maria Velho da Costa se bate com a herança imposta, optando pela fratria a que Manuel Gusmão se refere no prefácio da obra em leitura. ${ }^{5}$

De acordo com Heráclito, o logos não revela, sinaliza, e Sara está conscientemente atenta a esses sinais: tudo lhe fala. Ora, poderá ler-se uma dupla interpelação nessa audição, de semblante poético: no gesto de Sara trata-se de libertação que simultaneamente a coata porque, como refere, "o que não se diz do fascismo é que aleija toda a gente, para sempre" (Costa 2016: 310), e, no da autora, de busca não de um passado, mas de uma origem, essa afinidade eletiva que convoca autores e obras num processo intermedial e polivocálico, pois tudo nos fala. Sob esta convocação virão vários, José Régio, Camilo Castelo Branco, Agustina Bessa-Luís, Bernardim Ribeiro, Maria Gabriela Llansol, Guimarães Rosa, Maria Teresa Horta, Nuno Bragança, outros ainda, como Duras e a irreconciliação do quarto fechado, e talvez Deus, demiurgo que se destrona, ou pelo menos se namora, no riso último da que escreve a palavra. Esta linha de leitura pressupõe as teorias estruturalistas, iconoclastas na reprovação do autor. Maria Velho da Costa parece cruzar essa linha sem, contudo, deixar de a descruzar simultaneamente. ${ }^{6}$ 
Ora, este exercício intertextual resulta de uma inscrição do emissor do discurso no mundo essencialmente como ouvinte do mesmo e não apenas ou sobretudo na posição de falante ou locutor. De acordo com Gabriel Bergounioux, em Le Moyen de parler, entre outros textos, ${ }^{7}$ na peugada dos estudos na área da Psicologia desenvolvidos por Vygotsky e Piaget quanto à noção de linguagem interior, a voz enunciativa deve ser entendida como um sociograma, uma modelação criada sobre outras vozes (apud Harmann 2007: 40). De facto, Bergounioux propõe a reflexão sobre a linguística não somente sob o habitual ponto de vista do locutor, mas atendendo ao lugar do ouvinte (apud Chevalier 2010). Sob este pressuposto, o fenómeno da linguagem interior surge como um discurso alicerçado sobre a voz de terceiros, pois, como defende Jean-Claude Chevalier, no fenómeno da comunicação e da língua, o indivíduo de palavras não é ativo nem passivo, antes, um lugar intermédio de permuta, intercâmbio. ${ }^{8}$ Esta troca ou mutualização, de facto, formaliza uma rede de amplitude considerável em que, artisticamente, se reconhecem outras vozes num enunciado e se individua uma voz própria sobre, ou entre esse gozo eufónio e estético da língua poética. Parece ser o caso deste painel, Missa in Albis. Mais do que um tinir de outrem, a emergência da voz interior, comparável a um gesto de apropriação do dizer do contexto em que se movimenta, é também um fenómeno de individuação de semblante junguiano. Neste caso, este processo de construção do $e u$, no contexto literário e discursivo, entre o outro e a idealização de um outro-eu, não prescinde dos outros poéticos, e rende-lhes homenagem, na mesma medida em que Bergounioux defende, quanto às audições de outrem no discurso do eu, a homenagem ou a dissonância, a recusa ou a filiação (apud Harmann 2007: 40). Assim, e se a endofasia (discurso ou linguagem interior) constitui um desafio para a linguística, como refere Chevalier, em "La parole intérieure", a propósito do trabalho de Bergounioux, e se entendermos a emergência da voz como modelização de um processo de recusa e filiação, o sentido desta palavra cabe aqui sobremaneira. De facto, trata-se da proposta de leitura do discurso de Maria Velho da Costa como construção de um eu possível, de um eco produzido interiormente e reproduzido como testemunho da presença do emissor-escutador no mundo. Não será de somenos o tinido de Sara na obra estudada, bem como as impressões de audição e surdez recordadas ao longo do texto. Da mesma forma que para Jacques Nassif a voz é um instrumento de diferença e que no início é sempre a de um outro aquela que se faz audível (apud Harmann 2007: 42), neste contexto, a audição projeta e amplifica um eu dotado de múltiplos. Com efeito, o dialogismo bakhtiniano, a polifonia da interação textual, legível em Missa in Albis, pressupõem uma estreiteza conceptual com a noção de escuta e perceção do mundo. De facto, se rappeler, dire e entendre (cf. Chevalier, "Le parole intérieure"), são estruturantes como discurso do eu e, paralelamente, do discurso literário. A memória é fundacional como processo de reconstrução dos discursos audíveis e emergência de uma voz interior.

Poderíamos dizer, de forma superficial, que a afasia é, então, um [não] discurso de anulação social, e a endofasia, por seu lado, um exercício de perceção do outro e de inscrição do eu no mundo. ${ }^{9}$ Fazendo, assim, transmigrar estes conceitos psicológicos e linguísticos para a literatura, nomeadamente para a poética de Velho da Costa, sublinharíamos o conceito de 
endofasia enquanto figuração do seu discurso como resultado de um compromisso com o dos demais textos, numa rendição à alucinação auditiva, o que sublinha continuamente a perspetivação do discurso na sua aparição sonora, formal, essencialmente poética, melódica. Como tal, qualquer análise discursiva de um emissor em Missa in Albis será a reverberação de outros.

Como tal, intentar um estudo comparatista na obra de Maria Velho da Costa é transbordar. Comparar tecidos com uma outra voz é fazê-los emergir de um substrato profundamente nodoso em que compactuam diversas naturezas pelo entrelaçado que vem à superfície, sempre manchadas pelas demais. Segue-se, portanto, em bloco, nunca a direito, nem a dois. Sob este pressuposto, a intenção de ler a religiosidade, a passionalidade e o misticismo de Régio em Sara, embora não gorada, seria limitativa se não posta em diálogo aberto com outros semblantes, os quais, permeabilizando a personagem, a compõem e reconfiguram.

Se a poética regiana repete o tópos do numinoso na presença obsessiva da figura divina, não deixa de ser fundamental, embora atendendo (ou precisamente atendendo) à associação do autor ao movimento presencista, questionar tal ardor desinquietante: esta paixão efervescente trata-se de encenação ou de sinceridade? ${ }^{10}$ Discute-se, aqui, não uma sede voyeurista de contornos biografistas, antes, a constatação do assinalável binómio arte/ vida, em torno do qual a poética de Maria Velho da Costa tão amiúde (sempre?) gravita. Em José Régio, o Eu Superlativo, ${ }^{11}$ Manuel Nunes, referindo-se à correspondência entre Régio e Jorge de Sena a propósito de uma biografia que então o último estaria a preparar sobre o "poeta em estado místico", como assim o apelida José Augusto Seabra, ${ }^{12}$ conclui o seguinte:

diga-se que o que Régio faz na resposta enviada ao seu camarada de letras [...] é dar uma indicação sobre a forma como devem ser lidos aqueles seus textos de fiç̧ão e poesia. Por outras palavras, é dizer qual o pacto de leitura que lhes deve ser aplicado, no caso o pacto autobiográfico, fazendo assim da mentira da arte o espaço privilegiado em que se poderá ler a verdade da vida. ${ }^{13}$ (Nunes 2012: 99)

Ora, entre o espaço biográfico e a tendência para a despersonalização ou dispersão do $e u$, semelhante aos de Mário de Sá-Carneiro, ${ }^{14}$ sublinha-se a tensão dramática, segundo José Augusto Seabra, entre a identidade e a alteridade. Se Sá-Carneiro é figura tutelar de Régio, a insatisfação, a vivência em suspenso, polifacetada, e uma certa megalomania que lhe são legíveis perpetuam-se na poética regiana, abrindo um feixe de luz para a figura de Sara, como se atriz em palco rodeada de máscaras de que pode ir dispondo.

A irreprimível atração pelo abismo, quer de Sá-Carneiro - contrafator de eus - dos sujeitos poéticos regianos, quer de Sara, ${ }^{15}$ vem de longe, de Nietzsche e Kempis, aliás, ambos citados por José Régio nas epígrafes de Biografia ("Quando se ama o abismo é preciso ter asas" (Régio 2001: 111)) e de Poemas de Deus e do Diabo ("Neste abismo é que tu me fazes conhecer a mim mesmo" (idem: 44)), e relembrados por Maria Velho da Costa, pelo menos Thomas von Kempen e a sua De Imitatione Christi, em Missa in Albis. Nesse sentido, extrapolando, talvez a autora olhe de igual modo, fixamente, para ele por intermédio das figurações ficcionais. Por outro lado, a tensão e o homoerotismo resultante de A Confissão de Lúcio e de O Jogo da Cabra 
Cega, entre outros exemplos - dos quais destacaria o poema de traços dramáticos "O papão" e aquele que na obra de MVC se toma como citação direta, "Carta de Amor" cujo objeto de desejo parece variar, hibridamente, entre a "Querida" e uma figura divina ou, pelo menos, cristiana, acentuando-se algum pendor erótico - não deixam de ser intuídos em Missa in Albis.

Portanto, o vício de compor personagem é um rigoroso artifício presencista, não obstante a sinceridade almejada no papel, acentuando o jogo interior do primeiro modernismo. ${ }^{16} \mathrm{O}$ gesto, na ficção, é o que se faz contar. O traço romântico, quase barroco, regiano esbate-se num sentido metalinguístico e segue na senda do pluralismo vocálico, como um jogo sem extenuante possível. De facto, a simulação, enquanto palavra-chave, assentando no inexplicável porém audível, como se de um matema lacaniano se tratasse, ausculta, sob diversos pontos do poliedro, reto ou oblíquo, o humano, e a matéria artística opera sujeita a "uma leve aura poética de desentendimento" (Guimarães 2017).

Estas dicotomias entre vida e arte, sinceridade e fingimento, pensar e sentir serão talvez um logro que importa jogar até ao infinito enquanto mote, mas que irremediavelmente curvará para dentro ("quem sofre - pensa; e o tormento / Não é sofrer, é pensar" (Régio 2001: 250), tendo em conta a dualidade fera e irresolúvel, pois a sensibilidade há de ser uma forma de pensar, um terceiro estado, talvez o da paisagem, como Maria Gabriela Llansol lembrou.

O que se escuta de Régio em Sara? O misticismo, a exibição martírica, o acerado conflito entre carne/ espírito sem conciliação possível parecem as semelhanças mais vivas. Mas e o que há de Régio em Simão, enquanto figura trinómica de Sara? O diário regiano menciona amiúde, confessionalmente, o excesso carnal e a sua anulação casta enquanto sublimação do espírito, por contraste e elevação. O exacerbado desejo é tonificado como seria o de um penitente, mortificando-se, não deixando, porém, da dor colher o prazer negado ao corpo por via amorosa. Não raramente se sublinha a perversão, o vício, a obsessão (e atenda-se ao pejorativo associado à sexualidade). Esta mortificação é explicada por Isabel Ponce de Leão:

Tragado por um desejo de absoluto, luta contra a escravização da carne, denegrindo as práticas amorosas, e vendo no amor terreno uma insatisfação permanente e uma colossal limitação do género humano. Contudo, o arrebatamento carnal nunca o abandona e, por tal, surge o conflito irresolúvel: a entrega com inocência é utópica; o desejo carnal é condenável. Ocupando a mulher em toda a sua obra um lugar de destaque, debate-se numa impossibilidade de posse total que exacerba o desejo, fomentando procuras arbitrárias e até, por vezes, pouco seletivas. (Leão 2014: 204)

Ora, esta relação de expetativa, de proximidade e adiamento, é bem o espelho das ações de Sara e Simão, impossibilitados carnalmente, num ludíbrio do corpo perpetuador do desejo, como se, ainda assim, e de forma muito durasiana, o diálogo e a posse total do outro fossem dissonantes e impossíveis, tanto mais não seja pelo facto de o sujeito cartesiano se encontrar completamente estilhaçado. De facto, também a figura de Simão, retomada nas dos irmãos, se carateriza por um certo sentido do vicioso, reiterado numa condição inclusivamente enfermiça, de ordem patológica. 
Cadernos de Literatura Comparada

A Paixão de Sara: uma carta de amor regiana ou a errância em três tempos

\section{Dois - "sem explicação mútua não há mistério" (MVC)}

O sofrimento retirado do "prazer em me acusar e me exibir!" (Régio 2001: 250) é fórmula visível nas personagens da obra em estudo. Os evangelhos de Missa in Albis, ${ }^{17}$ apócrifos, descrevem a paixão de Sara, observando-a sob lentes múltiplas ("olhos poliédricos" (Costa 2016)), pois ela é a de muitos nomes, paródia de um princípio abraâmico que Bessa-Luís retomará depois em Vale Abraão, nessa encosta de homiziados. Mas a onomástica multíplice não é parte integrante de um simples ludismo narrativo, questionando, antes, esse introito mistificador do narrador, tomando-se ainda nomes de outras ficções, como Zana, num monólogo com $A$ noite $e$ o riso, a fusionalidade amorosa, a impressão de ser mulher e dada a talentos nos anos 60, e do princípio castrador a que parece, no caso da Missa in Albis, intim[id]ar os homens, dada a periclitante atmosfera de contestação da sua, cito, "ferocidade varonil" - já em Novas Cartas Portuguesas o desejo feminino se descreve, aos que o olham de viés, como princípio de impotência masculina.

Estas homenagens que Missa in Albis rende alucinam o texto num diálogo, estabelecendo-se ele mesmo nesse lugar verídico da ficção. Não se trata apenas de pastiche, montagem; já não se convoca liminarmente o intertexto, antes se constrói com ele na mesma dimensão. Rito de mostrar o braço que encena, na intuição de salvar do mergulho em apneia no simulacro. Aliás, quando Maria Velho da Costa questiona se será capaz de manter a revelação quando todas as vozes perecerem, - (lê-se em Missa in Albis, e é a autora, aparentemente, quem se alucina: "Um dia que te pereçam todos, isto é, num horto não oiças os teus olhos e ouvidos, poderás continuar a revelar?" (Costa 2016: 395) - indicia justamente essa perceção última da denegação de autoria, a favor do conceito de apropriação, fazendo vingar o texto como eterno palimpsesto. A escuta opera, então, o rigor do dizer, como se, na verdade, a língua não pudesse prescindir do recetor-auditor e o discurso interior se fizesse inteligível por meio dos outros. $\mathrm{O}$ discurso engendra o discurso, e o eu surge inscrito na língua como preceito social, de acordo com os preceitos lacanianos.

A paixão de Sara evoca um semblante tripartido assente na alegorização do Amor, de Deus e da Morte. O Amor de traços íntimos, engastado em Eros, viabiliza, paralelamente, a consideração de Justiça ou desejo de Beleza, de elevação. Trata-se de um rito, iniciação dos amantes, comparável ao dos catecúmenos, pelo que a consumação do amor, nesta obra, a par, por exemplo, de Myra, é adiado com o rigor apaixonado de neófito. O amor de Sara e Simão é toldado por um princípio lírico regiano, oxímoro religioso, de feição mística, ou mítica, na carnavalização de um estado de crença, pretenso ritual para adivinhação do Paraíso. Trata-se do gesto em detrimento do ato ou da vaidade de estar cindido, alardeando a dor, e ainda do prazer de adiar a reunião que se quer sacra, atingindo dimensão extasiante, pois só o ritual pode retornar o estado divino. Uma imitação de Cristo, pulsão redentora das imperfeições narcísicas e exibicionistas. De facto, sempre que Sara e Simão se encontram, o contexto emerge de uma recriação sacramental ou mítica, como em "Preparação para o sacrifício", em que os gestos reforçam a subversão do ato eucarístico à mesa da leitaria, vertido o cálice, evocada a samaritana ${ }^{18}$ e Veró- 
nica. Na verdade, como na celebração da Eucaristia, também esta Missa profana prevê o discurso enquanto construção rítmica, dado o dinamismo responsivo e o dialogismo, ou o facto de ambos os enunciados se poderem tomar por dialógicos e todos os discursos como réplicas.

A visita ao museu encontra-se igualmente imersa em simbologia religiosa, destacando-se as figuras da Madona e do Menino, de João Batista e Salomé, bem como todo o género de martírios. A cada passo, o par se encontra em espaços ajardinados, referenciando-se o jardineiro e a Obra. Na base desta simbolização, a escrita. A escrita, o amor e a religião envolvem-se como trio desaguado em círculo, serpente de Ouroboros, cujo rito se procura herético na desconstrução do mesmo. Talvez seja por via da subversão herética e do profano que o sagrado, se imperar em Missa in Albis, impere.

Podemos, a esta luz, ler os amores de Sara e Simão como a teatralização oxímora patente em "Carta de Amor" dada a informação do amor facínora, se considerarmos o lugar vazio da mãe, paixão que não demove, tido o amor como alegoria: o mundo não ama, pelo que o rito cristão, afeto ao rito amoroso e ao rito revolucionário, se invalida. A palavra de Deus, a ficção e o amor são questionados na mesma proporção, na instituição ou na forma institucionalizada. $\mathrm{O}$ ato sexual, em traços heréticos, torna-se confluente com a eucaristia e esta com a revolução, se tomarmos Sara como corpo de Cristo, a que não é inteiramente tomada. Toda a reunião acaba violentamente, impossibilidade real de amar. O pessimismo, a paródia e a comédia tornada trágica advêm desse desconsolo, descrença dos iludidos do amor, da revolução, de Deus e da Humanidade. Os ritos iniciáticos culminariam com a celebração efetiva do sacrifício de Cristo, alcance salvífico. Mas, como reflete Baltazar, quem é que pode estar sempre a ressuscitar? Não é à toa que todos questionam a culpa e procuram refrigério na alucinação da morte da mesma. Neófitos, todos, no amor, no sexo, na revolução, sem que se saiba se, ultrapassado o rito, são, como refere Tineta, meros insignificantes, "repesos de culpa" (Costa 2016: 370), a quem o rito parece nada ter acrescentado. Assim, o coito que não foi (com interrogação e provavelmente no plural) de Sara, como a missa campal, como a biografia - a escrita - são imprecisões, impossibilidades, mesmo se consumadas. ${ }^{19}$

Por outro lado, o rito é constante na repetição dos motivos: os amores infelizes, o trio, a relações incestuosas - Regina, Ema, Saul, Simão e irmãos, Aleixo e Salvador, e também os gatos anilados, animalização da flor novaliana. O rito é de tal forma visível, que se faz traduzir por via de um imensíssimo prazer na manutenção de uma relação cujo princípio dissuasor do corporal é altamente místico, dolorosamente deleitoso. Um verdadeiro ritual de iniciante, na perpetuação de um estado de desejo infinito.

Nesta tensão dramática vive Sara entre a sua identidade (ou o seu ID) e a alteridade, respondendo a Zana e à sua vigília subliminarmente, já que, aquela, ao estar "dans l' amour" faz "o ponto da situação dos companheiros" (Bragança 2003: 199). Mas Simão, que parece impotente perante Sara - numa menção à sua ansiedade depressiva e complexo de feminilidade, agressivo em relação à figura feminina, em fantasias de superioridade, retidas da relação diádica com a figura materna morta ${ }^{20}-$, e como se a faculdade de ela se fazer mulher o castrasse, ${ }^{21}$ escusa-se desse lugar de união e cega. Sara esforça-se, porém, em fazê-lo escutar 
num arremedo de atenção cósmica, fazendo-se cristianizar, em "etapas de noviciado" (cf. A Noite e o Riso) que os trazem em permanente desejo - e o desejo move, é só o que move.22

A paixão desembainhada dificilmente é consumada, quer no poema "Carta de amor" ${ }_{23}$ - e sublinhe-se Régio enquanto poeta na peugada do desvendar ôntico do humano na poesia e o consequente pessimismo antropológico, que Sara e, em última leitura, a obra de Maria Velho da Costa também retratam -, quer em "Adão e Eva", sonho do encontro da alma perdida (e recorde-se o reconhecimento de Sara e Simão assim que são apresentados), sonho em que se morre e ressuscita no corpo agonizante, e para se saberem, Adão e Eva, enfim malditos. O amor é sempre tão dificilmente consumado na poética de MVC:24 nas mortes violentas dos amantes, na mutilação sublimada nos sempre amores de perdição, pois não existe felicidade desterrada, exilada dos demais.

Neste sentido, a elevação do amor, sensual também, é, ao modo de Zana, uma comunhão total. Ou seria, se fosse consumado, na prevalência do todo no gesto individual, na exuberância da vida, como Bataille apelidou o erótico, a intensidade do espírito humano.

Se o mito do andrógino decepado se antecipa - pela referência, aquando do encontro de Sara e Simão na leitaria, ao zunido da máquina de fiambre decepando, a referência ao "outro aleijado" e aos catorze pedaços "partidinho [...] que nem a alma se lhe aproveitou" (Costa 2016: 50) -, também a sua manutenção nesse estado de impossibilitada comunhão: seja por inviabilidade social que se pretende combater, seja por meio da própria dispersão identitária individual, seja por última intuição de que 1+1 ainda carece. Para Martim, chocado, tal "união" seria "escura e numinosa, aniquilamento em ser mais, com outro", uma "blasfémia", portanto (idem: 226). A carne aqui, porém, é a grande elipse - myse en abyme, o coito que é um coito, ou o Rashômon ("sem explicação mútua não há mistério" (idem: 299), e Sara há de negar-se terminantemente no filme, como se lhe fosse também imiscuição ficcional: "a verdade é que este crime e este coito não foram", diz ela, (ibidem), denegando que "mesmo o que é visto possa ser" , apelando à rede ficcional, como se a paródia e o filtro protegessem - "chegas aqui e é onde desconstróis" (idem: 400), diz a voz narradora contando do quarto escarlate, sem que esta menção seja aleatória. Afinal, trata-se da apropriação do desejo, sintonia metafísica.

Mas que desejo? De Simão ou de Deus? E que narcisismo exibicionista regiano o de Sara, ou de Sara por mão de Simão? "Já fomos um só ser" (idem: 208); "Quando me perdi de ti, perdi-me de Deus ou Deus perdeu-se em ti" (idem: 244), afiança-lhe ela, em eco do mito andrógino e da queda no mundo profano. Deixa, entretanto, de ouvir sinais de delicioso terror, afasta-se de Simão, esse cálice, e afasta-se de Deus, dessa exibição a Cristo pelo amor trágico. Ainda assim, não se sonegam, que Simão, refeito do ciúme, toma consciência: "esta cara há-de acompanhar-me até ao fim e trespassar todas as outras", "o rosto da tua morte" (idem: 246), confirma Sara, esse ressurgir no outro, como, aliás, Bernard dizia ao Puto sobre Zana (A Noite e o Riso). Trata-se da nostalgia de continuidade, resultando na obsessão da supressão da condição individual por via sexual, erotizando o quotidiano, e sacralizando a existência, numa verdadeira experiência mística, enquanto interrupção do descontínuo, da profanidade.

Nesta relação, firma-se a comunhão com a figura de Deus, no que é e se nega, na injunção 
do indefinido, como sacramento lícito mas não válido, ritos de cujo efeito se descrê mas constituem blasfémia ainda assim, uma culpa que não sara. De que forma se constituirão as constantes declarações de Sara a Simão antes a Deus, a par do sujeito poético de "Carta de amor"? Quem é recetor desta carta? A amada, ou a figura divina? "Não, não é a ti que me eu declaro!", exclama o poeta, e por isso, Simão retorna a Sara: "falas com maiúsculas, o Amor, a Justiça, Deus" (idem: 251). Ama-se aqui o Amor ou um sujeito amoroso?

O ciúme de Sara é também palpável (idem: 257), ${ }^{25}$ bem como a busca pelo mesmo gosto do abandono do primeiro amor (da figura maternal, como Simão), ainda a noção de pecado, aliado à culpa, também a abstinência corporal. Rito que não é, até com Aleixo: "o que é que não tinha acontecido naquela cama?" (idem: 317), quando percebe que vir também é um verbo reflexivo, erosão das erosões, aparição de si, troca de faces, petite mort e ressurreição, e ninguém lhe havia dito nada, ela, que supostamente pensa em Simão em momentos menos oportunos. Um coito que não é e é na ausência de outro?

Mas trata-se efetivamente de um rito de paixão, o da Sara, ou emulação? No ver de Tineta, ela é de "arrebatamentos [...] compostos de emocionalismo inveterado", porque "não é a paixão que faz estragos, mas a sua mímica" (idem: 334). Sara crê ou não se alcança? E é justamente este paramento para a dúvida, esse ato de fé, que estimula a proximidade entre Sara, especialmente de uma fase inicial do romance, com o sujeito poético de "Carta de Amor". Diante da dimensão do sagrado - a aporia regiana, legível na hesitação de Sara, ainda que parodiada. O riso há de ser arma contra o medo e a culpa - comic relief da tragédia em curso - e também a morte, em caso de dúvida. Régio viabiliza a dificuldade lógica; verseja como quem reza, contra. A duplicidade do sagrado de Régio infere um Deus que fere e consola, e um amor humano precário e limitado. Essa duplicidade perpassa o texto de Missa in Albis, na busca para rejeição de Deus, desejo que move para o nada, e a precariedade do amor, enfim, da vida, irresolúvel, dado ser sempre um Cristo crucificado aguardando vida o que desperta o desejo insinuado de totalidade.

Mas comparar só Sara ao sujeito poético regiano é olvidar Simão, essa metade que a nega, afinal: "não a amei nada, nunca senão a vaidade dela" (idem: 459), "tarado beato e inofensivo, para Sara, contra Sara". Régio havia escrito: "Tu... a minha metade!/ Por isso me não és senão vaidade [...] meu pretexto/ Deste miserável texto" (Régio 2001: 251). É que Simão queria-a intacta e inteira, e ela, afinal, "precisa de conceder, como toda a gente" (Costa 2016: 460); "és de facto tentada?", perguntara-lhe já, no primeiro encontro que espiamos (idem: 47). É Simão quem mantém Kempis e a sua Imitação no seu quarto, é ele quem constrói Sara cristiana e di-lo enquanto reza a Sixto, o único capaz de o ouvir dizer-se. É ele, enciumado, quem a desenha adúltera; a sexualidade dela castra-o. Assim, compara-se aleijão a Sixto, "crias da última geração que se quis grotescamente épica e apenas deixou cicatrizes [...] recuerdos venéreos [..] no seu "priapismo pânico", ${ }^{26}$ vivência amargurada. Simão perfilha Sara, irmana-a, qual Abraão, e disputa-a, duplicado em Sixto, o sexto (sempre o 3 e os múltiplos de), enciumado de Salvador ou de Sara feita Salvador e pai, da sua quase partenogénese ficcional. Simão procura- 
-se, dual: é Sixto, nesse corpo estropiado, imagem e semelhança, "és como o Cristo ainda vivo retirassem-lhe um prego" (idem: 457). Sara há de dizer-se pretexto de expiação de Simão, "de não serem senhores de tudo", já que não têm idade "para serem sovados com a mãe a ouvir sem se danar" (idem: 448), numa visão muito pouco mariana nesse gólgota urbano, que Régio sublinha: "vício antigo/ De me lamber as mãos e agatanhar o peito,/ De me exibir a Cristo!" [...] Sabe (se é que o não sabes)/ Que ao teu amor por mim foi que ganhei amor" (Régio 2001: 252). Aleixo também fará dela mulher fatal, "tem que minar o que é macho", "escreve contra mim", há de reclamar (Costa 2016: 450).

Perguntamos, então, se se convoca aqui o sagrado, ou apenas um princípio de habituação mitificante, um veio religioso da repetição ritualística insolvente, como quem ouve missa por hábito, como quem faz revoluções por princípios depois inacabados. Salvador há de dizer que Sara e Simão têm ambos a esperança posta no passado (idem: 433), como quem discorre sobre a crença: ressuscita-se? Enfim, carnavalização. E a escrita: ludismo ou sacramento? Aquando da "confusão de vozes que sussurram um amorável coito", há de justificar-se a perdição de Sara: "Sara se está perdendo, e o seu espírito e o seu corpo, por um fenómeno que é o tomar por recreação um estado que devia ser vivido com solenidade: a disposição às palavras. Sabe, na qualidade de sintoma, [...] que é possível alcandorar-se [...] um lugar temido: a pura luz. Lhe há um sol" (idem: 394). Sublinhe-se o fascínio da eufonia. Esta Sara tem matizes de Llansol.

E é neste reduto, o da audição, que se dá a comunhão, o religare, o aparato religioso da palavra, litúrgica e poética: de escrever contra a memória, para o legado, e não a herança, desdobramento de figura contra a biografia, num ato é[s]t[ét]ico (estético que se lê ético). "Acto de amar que era o acto de escrever", postulará depois Maria Gabriela Llansol (2016: 111); "nenhum contacto humano directo vai tão longe como sinto que pode ir o acto de escrever", confessara Bragança, pela boca de Zana (Bragança 2003: 199), "Vemos, ouvimos e lemos. Não podemos ignorar", escreverá Sophia de Mello Breyner Andresen, em "Cantata de paz", pelas vigílias: um poeta, enfim, vigia.

O desejo, também regiano, herético (erótico?) de se ver como Cristo, ou Deus, no limite (e de que forma questionar a noção de autoria não é questionar a fé e Deus?), é fracasso se não for na escrita: "se contasses, acreditavas" (Costa 2016: 51). No poema de Régio lemos, sobre as "coisas que, ditas, já não são verdade": "procuro eu dizê-las/ ou procuro escondê-las?" (Régio 2001: 251). E há de Tineta concluir: "a fala do Senhor se tinge da voracidade do amante enciumado, excitado pela invocação do nome cujo corpo falta" (Costa 2016: 472). A morte e o desejo, ritualistas e eróticos, de Sara e Simão, são sinal da vivência/ simulação religiosa do amor.

Três - os quartos escarlates e o número primo

Ora, como vemos, o erotismo, a violência e a morte são recorrentes na obra de Maria Velho da Costa, a que, e no caso em estudo, se pode atribuir um profundo sentido religioso. Na figu- 
ra de Sara pode ler-se uma entrega sem concessões ao amor divino, gravitacional da morte, sofrimento a que Sta. Teresa d'Ávila, S. João Batista e S. Sebastião (estes em representações artísticas de semblante andrógino e homoerótico) também se entregam. Eros e Thanatos, portanto. Segundo Bataille, a união dos amantes dá-se por efeito da paixão invocadora da morte, desejo de matar ou matar-se, "This aura of death is what denotes passion" (Bataille 2012: 20): recorde-se Simão decifrando a casa onde vive Sara, encontrando-a no jardim, com Salvador, com quem Sara forma uma só sombra, que se interpõe, e este mesmo há de ter ímpetos de matar quer um, quer outro, tendo ensaiado já a própria morte (como a alucinação de Sara e da sua morte, aliás, e as loucuras intermitentes de Salvador). Os três desavindos, descontínuos, no jardim.

Essa noviça, beguina, sempre tida como herege e tarada, alucina a morte como quem alucina a vida, é coisa de ficção que não é, faz-se toda numa palavra. Corpo de Cristo insalubre, ou recusado, morte contra a morte do amor, da revolução, contra a própria morte (Costa 2016: 511). Delírios de Sara, "sem distinguir ninguém" (idem: 515), trocando-lhes o nome, e há de a filha de Martim (a pequena Maria, agnóstica) lembrar a localização dos lares de Sara e Simão, correspondente ao périplo do teatro romano de Caius Heius Primus, Lisboa-palco, chave d'ouro shakesperiana, "É pensar que estivestes a sonhar, foi tudo visão no correr desta sessão". ${ }^{27}$

Ao princípio de fusionalidade de "Carta de Amor" e de Zana (a que vela pelas cinco, hora a que Sara acorda para abençoar seus fiéis), responderá Sara com a amplificação do terceiro corpo. De facto, este quarto escarlate remete diretamente para Maria Gabriela Llansol, para os seus Contos do Mal Errante, e para os quartos dos olhos imóveis de Isabôl, a cena fulgor, as difíceis reciprocidades (Llansol 1986).

Alcançamos assim Salvador, Agnus Dei, sacrifício para resgate do pecado original, da imperfeição, mal congénito e hereditário; é personagem-síntese, coincidência e superação, como Diadorim rosiano, como a poesia; "está-nos na massa do sangue" (idem: 89), reflete Simão, muito agostiniano, quando conhece Sara, aflorando o pecado e a culpa de que todos os narradores se queixam afinal nesta Missa in Albis. Sal, chama-lhe a mãe. O sal liga, como reflete o capitão de Goethe n'As Afinidades Electivas, "desejo pronunciado de união", "afinidade de espírito ou de alma", já que "reunir é arte superior" (Goethe 2017: 62-63). O próprio Simão o reconhecerá, ainda que irónico, no papel de rei Cofétua, quando afirma que ela, Sara, pode sempre regressar, descalça, mesmo sendo Salvador a trazer-lhe os sapatos na mão.

O número $3^{28}$ é repetido constantemente, no que de sacro alumia, e ler-se-á porventura mais pronunciado em Myra, no desenho daquela, de Orlando e desse cão poético. Porque enquanto se é feminino e masculino há um estado de preanunciado antagonismo dificilmente ultrapassável pela palavra estanque a que são remetidos. Procura-se um terceiro estado, sempre adiado, lugar do a-topos, como morte em vida e o [des] escrever. Na ausência de um, quebra-se a segurança dos três, pelo que se anulam individualmente. Esta alegoria ultrapassa o enredo e prende-se diretamente com a teorização literária, à necessidade implícita de um leitor. "Manda-me dizer onde estás", pede Simão a Sara comovida. Entre o que é e o que não é, ${ }^{29}$ 
regiana sedução, síntese contraditória, há um apelo ao ritmo, pulsão celebratória da eufonia: "Talvez seja assim que se formam os poemas, uma voz alheia que o frémito convoca" (Costa 2016: 125). ${ }^{30} \mathrm{E}$, ainda assim, ela lhe morre, como lhe parece, "numa casa sem dono", e "tantas veredas", o ser que ele denegou em si e que forma monólito com Salvador, simbiose que Simão negara, "hercúleo contra o seu próprio amor" (idem: 522); eu diria contra a sua própria face. Trocar de vestes, ou misturá-las, teria sido essencial.

E se Régio critica os formalismos religiosos, a caricatura da religião, também Maria Velho da Costa parece fazê-lo, denunciando um rito que não é, como um coito que não foi, autobiografia que não soube ser: autobiografia rosiana, ou contar para a viver, diria Zana. O gesto ou o aparato em detrimento de qualquer resquício medular. Mostrar, por oposição ao ser, atitude de poseur brechtiano. ${ }^{31}$

Idolatria ou crença? Democracia ou vulto? Amor ou fome de amar? Talvez arda em Sara o empenho para a dúvida, mas também para o amor e a caridade em que os sistemas não souberam, à sua maneira, renovar. Salto para o absoluto estimado por Régio e ansiado por Sara, religião humana parodiante de si mesma e dos seus princípios democratizantes, conciliação dos inconciliáveis, religião essa que preferiu deixar em branco, aguardando a fala, em sarça ardente, de outrem: "Não mais, versos meus, palavras mortas [...] E nos silêncios do meu verso/ Fala tu" (Régio 2001: 339).32 Fala tu, "Se contasses, acreditavas", promete esta Missa (Costa 2016: 51). Pedido cósmico, primordial audição, toada universal, imitação de Cristo, latido contra o instituído? "Clamar alguém por Deus ou contra gera a mesma palavra" (idem: 519), mas quem não ouve, nem diz, é "alarve contra a possessão de modos, vivendo como numa crendice" (idem: 520), que o "acto de amar" é "como o acto de escrever" (Llansol 2016: 111).

Pretendia este trabalho sublinhar como a literatura em Maria Velho da Costa parece proceder de uma conceção particular, a da contínua voragem do palimpsesto, sem que os resquícios anteriores se remetam à ilegibilidade, e no qual se estimula e ouve claramente ecos de múltiplas vozes, como coro intransponível, dissimulação identitária barthesiana. Conclui-se que a emissão de discurso provém de uma voz interior caucionada pela escuta, isto é, pela perscrutação do mundo, sublinhando-se paralelamente a forma e a eufonia da palavra poética que parece oferecer uma capacitação sedutora e inteligível daquele (recorde-se Sara e a paixão pelo nome científico das plantas). Neste quadrante, a autora tende a afirmar a impossibilidade da escrita como monólogo, referindo-se ao discurso como projeção de um exercício de escuta de que ecoam versos e perspetivas múltiplas, de José Régio a Maria Gabriela LLansol, sobre os quais se operou uma proposta de leitura comparatista.

Por outro lado, sublinhou-se a (in)distinçao entre a matéria ficcional e a real como jogo e a consequente perigosidade de viver segundo a mão que augura a escrita, e ensaiou-se Sara como ritualista, a par de Ema, a da tesoura, que corta personagens, remetendo para o ludismo do fazer ficcional. Relativamente ao amor/ficção, no duplo lê-se a eterna dramatização da diferença hierarquizada, incomunicável. A noção llansoliana do amor ímpar é aflorada, bem como o desterro como consequência dos males de ciúme e preconização de uma díade compacta e univocal. 
Sara há de tornar, antes de morrer: "Averigua se ficámos assim quando desviámos os dentes do cordão umbilical" (Costa 2016: 523). Como?, perguntará Salvador, que com ela vela, ao menos uma hora, "Divinos", dir-lhe-á, ao que o andrógino, situando-se à beira Ebro, ou no rio que assedia Münster, convocará, num movimento de reunião, amor ímpar, o retorno ao Jardim inviabilizado, como coito berniniano, paixão e êxtase, lícito mas não válido, de Sara, Sal e Simão-menino, seres descontínuos, ${ }^{33}$ morrendo depois isoladamente numa aventura ininteligível, que Deus e a religião, por mais sacra ou profana, não parecem poder religar pela imposição de luta e denegação do compromisso: "tão profundo é[ra] o contrato que não pode[ia] haver disputa" (Régio 2001: 253). Amor primeiro, chama primicial, figura morta. 


\section{Cadernos de Literatura Comparada}

A Paixão de Sara: uma carta de amor regiana ou a errância em três tempos

\section{NOTAS}

* Cláudia Capela Ferreira é doutorada em Estudos Literários pela Universidade de Trás-os-Montes e Alto Douro com uma tese sobre o profano e o sagrado em Miguel Torga.

${ }^{1}$ Poema de Biografia.

${ }^{2}$ A propósito do vento e da fricativa alveolar sonora ([z]) como dois registos sonoros infantis de relevância para Eduardo Lourenço, Maria Filomena Molder, numa conferência, a 22 de setembro de 2019, no Porto, sublinhou a pertinência da escuta e da eufonia na poesia e no ensaio, sublimando esse movimento de interiorização e retorno.

${ }^{3} \mathrm{Cf}$. Um Beijo dado mais tarde: "Não ligues excessivamente ao sentido. A maior parte das vezes, é impostura de língua" (Llansol 2016: 129).

${ }^{4}$ Cf. o discurso de João Guimarães Rosa à Academia Brasileira de Letras, a 16 de novembro de 1967.

${ }^{5}$ Seria igualmente aceitável compreender tal gesto como um impulso no sentido de um "legado fundador" como João Barrento apelidou, no posfácio da obra em causa, a escolha de Témia de um Beijo dado mais tarde.

${ }^{6}$ Maria José Carneiro Dias explicita estas posições na sua tese, Maria Velho da costa: uma poética de au(c)toria.

${ }^{7}$ Consulte-se a edição de Langue française sob a direção de Gabriel Bergounioux, n¹32, 2001: "La parole intérieure".

${ }^{8}$ Leia-se Jean-Claude Chevalier (2010), "La parole intérieure", Modèles linguistiques 3|2010, <https://journals.openedition. org/ml/427> (último acesso em 29/06/2020).

${ }^{9}$ Tal como a figura do gago no prólogo de $O$ Espelho, de Andrei Tarkovsky, no qual se evidencia também o carácter metalinguístico pela intromissão da perche, que se diz finalmente, e se discursa, fazendo audível essa sua voz interior: "Eu sei falar!"

${ }^{10} \mathrm{~A}$ afirmação da sinceridade regiana, a par da torguiana, suspeitas (a verdade em Miguel Torga trata-se de autoficção, projeção na obra da imagem, construção balizada pela autobiografia e ficção), sujeitam-se à interrogação da sua honestidade, o que não a invalida naturalmente nas suas poéticas, no mesmo sentido que Jorge de Sena adianta, sobre Fernando Pessoa, assinalando a verdade em poesia como uma visão exterior à consideração de verdadeiro e falso (Confira-se a propósito Fernando Guimarães (2017), "Arquivo Virtual da Geração de Orpheu", <https://modernismo.pt/index.php/f/574-fingimento> (último acesso em 20/9/2019).

${ }^{11}$ Tese de doutoramento de Manuel José Matos Nunes: José Régio, o Eu Superlativo - o ciclo romanesco A Velha Casa e outros escritos autobiográficos.

${ }^{12}$ No prefácio a José Régio, Obra Completa.

${ }^{13}$ Continua: "Esta forma de narrar o eu entre a autobiografia, a ficção e a lírica constitui uma clara representação dum espaço autobiográfico, a intenção de transmitir uma imagem de si que se apreenda e perdure. Régio pode não assumir um tal programa de escrita, pode até criticar os propósitos do autor de Si le grain ne meurt - autor lido e relido pelos homens da presença -, mas a verdade é que também ele não escapou à inquietação de se explicar, de constituir pela escrita uma imagem da sua personalidade" (Nunes 2012: 99).

${ }^{14}$ Em Confissão dum Homem Religioso diz dos seus estados "mórbidos e nocturnos" que pendiam sobre o "eu ameaçado pela dissolução" (apud Nunes 2012: 101).

${ }^{15}$ Comparamos vozes, ainda que, atendendo às devidas diferenciações, se possa alinhavar a possibilidade de um estudo em torno da personagem enquanto prolongamento livresco de Maria Velho da Costa, no que de literária e socialmente geracional se implica: Sara, alter-ego de MVC e da geração soixante-huitard portuguesa?

${ }^{16}$ A meu ver, a presença, ainda que teoricamente contra-revolucionária, joga o mesmo jogo da geração anterior, mas ao contrário (é interessante que Eduardo Lourenço, num discurso explanatório do polemizado artigo "Presença ou a contra-re- 
volução do modernismo", consultável em Revistas, ideias e doutrinas, leituras do pensamento contemporâneo, afirme que foi a presença, aliás, a descobrir, isto é, legitimar a Orpheu, e que, no seu desconhecimento das diferenças entre ambas, é que tenha criado novidade, em vez de se constituir como mero movimento pleonástico de discipulado). Enquanto Orpheu, nas obras de Pessoa (mais claramente) e Sá-Carneiro, deflete as personae de dentro para fora, projetando-as múltiplas na parede, a presença, nos casos da poética de Torga e Régio, mostram-se unos, refratando a luz paradoxalmente para o interior, pejado de contradições entre a impulsividade narcísica, dramática, romântica e o equilíbrio clássico: o apolíneo e o dionisíaco.

${ }^{17}$ Evangelhos ou carmes, ao jeito amoroso e paródico, blasfemo, de Carmina Burana, apelando novamente a um sentido ritualístico da escuta e ao princípio eufónico do real.

${ }^{18}$ Será esta a samaritana de Ruy Belo, constante do poema "Nós os Vencidos do Catolicismo", de Homem de palavra(s)?

${ }^{19}$ No caso do coito, que possa ter sido, nunca o é inteiramente sem petite mort, e é favorável a interrogação do número de oficiantes, presentes também em espírito, já que Sara pensa em Simão nos momentos menos oportunos.

${ }^{20}$ Refira-se, a propósito, as patologias de vínculo de Melanie Klein e Donald Winnicott (cf. Hinshelwood, A Dictionary of Kleinian Thought).

${ }^{21}$ Até pela escrita, que Baltazar bem refere que lhes basta a vulnerabilidade, que os talentos são "salvo conduto para um abandono suportável" (Costa 2016: 361), até porque "quem é que pode estar sempre a ressuscitar"? (idem: 359). O ciúme do camiliano Simão, cegante, enforma este.

${ }^{22}$ Julia Kristeva (cf. Histórias de amor) enuncia o desejo como busca do objeto.

23 "Tão profundo é o contrato/ Que não pode haver disputa [...] Despi-me..., vê se me queres! [...] Vê se me queres,/ Sabendo que te não quero,/ Nem te mereço" (Régio 2001: 253).

${ }^{24}$ Constatamo-lo mais recentemente em Myra, confirmante da permanência da obra no lugar do mosaico ficcional, rede de amparo, com Orlando lupino de outro mote.

${ }^{25} \mathrm{O}$ ciúme, como preâmbulo do mal, é um assunto destacado em Contos do mal errante. Simão refere constantemente o ciúme; cega, inclusivamente, perante a noção do ímpar, por medo de exclusão.

${ }^{26}$ Talvez de duplo significado, concetualmente social, patriarcal, e como retrato de uma geração não só literária, a par do que Ruy Belo crismou de "Vencidos do Catolicismo", em Homem de Palavras(s), mas isso daria outro estudo.

${ }^{27}$ A fala de Puck: "If we shadows have offended,/ Think but this, and all is mended, - / That you have but slumber'd here,/ While these visions did appear./ And this weak and idle theme,/ No more yielding but a dream,/ Gentles do not reprehend: /If you pardon, we will mend." (Shakespeare 1996: 301).

${ }^{28}$ Uma referência a Le troisième homme, de François Roustang ou ainda à terceira coisa elogiada por Brecht? Sublinhe-se também o número de painéis de $A$ Noite e o Riso.

${ }^{29}$ E recorde-se a propósito o que foi apelidado por Antônio Cândido em "O Homem dos Avessos", em Tese e Antítese: ensaios, como princípio de reversibilidade em Guimarães Rosa.

${ }^{30}$ Recorde-se Sophia e a sua perceção da poesia: "Encontrei a poesia antes de saber que havia literatura. Pensava que os poemas não eram escritos por ninguém, que existiam em si mesmos, por si mesmos, que eram como que um elemento do natural, que estavam suspensos, imanentes. E que bastaria estar muito quieta, calada e atenta para os ouvir." (Arte Poética IV).

${ }^{31}$ Ainda a propósito de palavra, audição e inconsciente, ou de sujeito como produto de linguagem, leia-se o capítulo segundo da tese de Maria José Carneiro Dias.

${ }^{32}$ Pode ler-se no poema de José Régio, "Sarça Ardente", de As encruzilhadas de Deus.

${ }^{33}$ Cf. Georges Bataille, em Eroticism, implicando no conceito de reprodução a noção de descontinuidade: "Reproduction implies the existence of discontinuous beings [...] Between one being and another, there is a gulf, a discontinuity" (Bataille 2012: 12). 
Cadernos de Literatura Comparada

A Paixão de Sara: uma carta de amor regiana ou a errância em três tempos

\section{Bibliografia}

Andresen, Sophia de Mello Breyner (2011), "Arte Poética IV", in Sophia de Mello Breyner Andresen no seu tempo, Momentos e Documentos. <http://purl.pt/19841/1/galeria/artes-poeticas/ arte-poetica-iv.html > (último acesso em 25/09/2019) [1972].

Bataille, Georges (2012), Eroticism, London, Penguin [1957].

Bragança, Nuno (2003), A Noite e o Riso, Lisboa, Publicações Dom Quixote [1969].

Bergounioux, Gabriel (2001), "La parole intérieure", in Langue française, $\mathrm{n}^{\circ} 132,2001$. <https://www.persee.fr/issue/lfr_0023-8368_2001_num_132_1 > (útimo acesso em 29/06/2020).

Cândido, Antônio (2002), "O Homem dos Avessos", in Tese e Antítese: ensaios, São Paulo: T.A. Queiroz.

Chevalier, Jean-Claude (2010), "La parole intérieure", in Modélles linguistiques, 3, 2010, mis en ligne le 23 octobre 2013. <https://journals.openedition.org/ml/427 > (último acesso em 29/06/2020).

Costa, Maria Velho da (2016), Missa in Albis, Porto, Assírio e Alvim [1988].

Dias, Maria José Carneiro (2013), Maria Velho da Costa: uma poética de au(c)toria, Porto, Faculdade de Letras da Universidade do Porto.

Goethe, Johann Wolfgang (2017), As Afinidades Electivas, tradução de Maria Assunção Pinto Correia, Lisboa, Bertrand Editora.

Guimarães, Fernando (2017), "Arquivo Virtual da Geração de Orpheu", in Modernismo, Arquivo Virtual da Geração de Orpheu, IELT- FCSH, Universidade Nova de Lisboa. < https://modernismo.pt/index.php/f/574-fingimento> (último acesso em 20/9/2019).

Harmann, Fernando (2007), A voz na escrita, Tese de Doutoramento em Educação. Universidade Federal do Rio Grande do Sul.

Hinshelwood, R. D. (2005), A Dictionary of Kleinian Thought, London, Free Association Books. Llansol, Maria Gabriela (1986), Contos do mal errante, Lisboa, Edições Rolim.

- - (2016), Um beijo dado mais tarde, Porto, Assírio e Alvim [1990].

Leão, Isabel Ponce de (2014), "A confissão de Régio", in Revista Diacrítica vol 28, nº. 2, Braga, CEHUM.

Lourenço, Eduardo (2003), "Orfeu e presença", in Revistas, Ideias e doutrinas, Leituras do Pensamento Contemporâneo, Lisboa, Livros Horizonte, 93-103.

Nunes, Manuel (2012), José Régio, o Eu Superlativo - o ciclo romanesco A Velha Casa e outros escritos autobiográficos. Tese de Doutoramento em Estudos Portugueses. Universidade Nova de Lisboa.

Régio, José (2001), José Régio, Obra Completa, Poesia I e II, Lisboa, Imprensa Nacional-Casa da Moeda.

Shakespeare, William (1996), The Complete Works of William Shakespeare. London, Wordsworth Editions. 